\title{
Local Synthesis of Actin-Binding Protein $\beta$-Thymosin Regulates Neurite Outgrowth
}

\author{
Ronald E. van Kesteren, ${ }^{1 \star}$ Christopher Carter, ${ }^{2 \star}$ Helga M. G. Dissel, ${ }^{1}$ Jan van Minnen, ${ }^{1}$ Yvonne Gouwenberg, ${ }^{1}$ \\ Naweed I. Syed, ${ }^{3}$ Gaynor E. Spencer, ${ }^{2}$ and August B. Smit ${ }^{1}$ \\ ${ }^{1}$ Department of Molecular and Cellular Neurobiology, Research Institute Neurosciences, Vrije Universiteit, 1081 HV Amsterdam, The Netherlands, \\ ${ }^{2}$ Department of Biological Sciences, Brock University, St. Catharines, Ontario, Canada L2S 3A1, and ${ }^{3}$ Respiratory and Neuroscience Research Groups, \\ Faculty of Medicine, University of Calgary, Alberta, Canada T2N 4N1
}

Local protein synthesis plays an essential role in the regulation of various aspects of axonal and dendritic function in adult neurons. At present, however, there is no direct evidence that local protein translation is functionally contributing to neuronal outgrowth. Here, we identified the mRNA encoding the actin-binding protein $\beta$-thymosin as one of the most abundant transcripts in neurites of outgrowing neurons in culture. $\beta$-Thymosin mRNA is not evenly distributed in neurites, but appears to accumulate at distinct sites such as turning points and growth cones. Using double-stranded RNA knockdown, we show that reducing $\beta$-thymosin mRNA levels results in a significant increase in neurite outgrowth, both in neurites of intact cells and in isolated neurites. Together, our data demonstrate that local synthesis of $\beta$-thymosin is functionally involved in regulating neuronal outgrowth.

Key words: neurite outgrowth; local translation; local protein synthesis; actin cytoskeleton; actin-binding protein; $\beta$-thymosin

\section{Introduction}

Local protein synthesis is a well documented neuronal regulatory mechanism in axons and dendrites in the adult brain (for review, see Glanzer and Eberwine, 2003; Piper and Holt, 2004). In developing neurons, in contrast, little is known about the nature of the mRNAs that are present in outgrowing neurites and of the role of the proteins that are locally synthesized. Several studies indicate local protein synthesis as a general and crucial mechanism in the regulation of neurite outgrowth and synapse formation (for review, see Martin, 2004), but there is no direct evidence for a functional contribution of locally synthesized proteins to neuronal outgrowth.

Developing neurons would obviously benefit from a cellular mechanism that would restrict protein translation to particular subneuronal domains. As neurons become more polarized, growth cones need to control their behavior independently of one another and to respond to environmental stimuli in a branch-specific manner. Extracellular signals that regulate neurite outgrowth and guidance produce local changes in growth cone motility, allowing growth cones to change their direction and speed of growth. These alterations in growth cone motility are primarily determined by the dynamics of the actin cytoskeleton inside the filopodia (Dent and Gertler, 2003). Numerous

\footnotetext{
Received May 17, 2005; revised Nov. 7, 2005; accepted Nov. 7, 2005.

This work was supported by grants from the Netherlands Organization for Scientific Research (to R.E.v.K.) and from the National Sciences and Engineering Research Council (NSERC; Canada) (to G.E.S.). C.C. received an NSERC graduate scholarship, and G.E.S. is a recipient of the Premier's Research Excellence Award (Ontario, Canada).

*R.E.v.K. and C.C. contributed equally to this work.

Correspondence should be addressed to Ronald E. van Kesteren, Department of Molecular and Cellular Neurobiology, Research Institute Neurosciences, Vrije Universiteit, De Boelelaan 1085, 1081 HV Amsterdam, The Netherlands. E-mail: ronald.van.kesteren@falw.vu.nl.

DOI:10.1523/JNEUROSCI.4164-05.2006

Copyright $\odot 2006$ Society for Neuroscience $\quad$ 0270-6474/06/260152-06\$15.00/0
}

actin-binding proteins may be involved in the regulation of actin dynamics (Dos Remedios et al., 2003). As such, local translation of actin-binding proteins might provide a powerful mechanism in regulating growth cone motility and neurite outgrowth in a branch-specific manner.

One class of actin-binding proteins are the $\beta$-thymosins. $\beta$-Thymosins are small proteins that bind and sequester monomeric actin, thus preventing actin polymerization and formation of filamentous actin (Huff et al., 2001). $\beta$-Thymosins are particularly abundant in the brain (Devineni et al., 1999) and appear to be involved in activity-dependent structural plasticity (Carpintero et al., 1999). In zebrafish, overexpression of $\beta$-thymosin in cultured retinal ganglion cells results in alterations in neurite shape and excessive branching (Roth et al., 1999b), and in vivo knockdown of $\beta$-thymosin results in malformation of retinal axon tracts (Roth et al., 1999a). In a recent study, $\beta$-thymosin mRNA was shown to be present in neurites of cultured Aplysia sensory neurons (Moccia et al., 2003).

Here, we addressed the question whether $\beta$-thymosin can be locally synthesized to regulate neurite outgrowth. We identified $\beta$-thymosin mRNA as one of the most abundant transcripts in neurites of cultured pedal A (PeA) neurons of the freshwater snail Lymnaea stagnalis. We show that $\beta$-thymosin mRNA appears at specific sites within neurites, including growth cones and turning points. Double-stranded RNA (dsRNA) knockdown of $\beta$-thymosin mRNA levels in intact cells, as well as in isolated neurites, significantly enhanced neurite outgrowth, demonstrating a role for locally synthesized $\beta$-thymosin in the regulation of normal patterns of neurite outgrowth.

\section{Materials and Methods}

Animals. L. stagnalis were bred in the laboratory under standard conditions (Van der Steen, 1969). Snails of $\sim 2$ months of age (shell length, 20-23 mm) 
were used for cell isolation, and snails of $\sim 3$ months of age (shell length, $\sim 30$ $\mathrm{mm}$ ) were used to produce brain conditioned medium (CM).

Neuron culture. Single cells were isolated and cultured as described previously (Syed et al., 1990; Ridgway et al., 1991). In short, the CNS was isolated under sterile conditions and treated for $20-24 \mathrm{~min}$ with $2 \mathrm{mg} / \mathrm{ml}$ trypsin type III (Sigma, St. Louis, MO) in defined medium [DM; 50\% v/v Leibovitz L-15; composed of the following (in mM): $40 \mathrm{NaCl}, 1.7 \mathrm{KCl}, 4.1$ $\mathrm{CaCl}_{2}, 1.5 \mathrm{MgCl}_{2}$, and 10 HEPES, pH 8.1; Invitrogen, Carlsbad, CA], followed by treatment with $2 \mathrm{mg} / \mathrm{ml}$ trypsin soybean inhibitor (Fluka, Buchs, Switzerland) for 10-12 min in DM. After transfer to highosmolarity medium (DM containing $30 \mathrm{~mm}$ glucose), connective tissue sheaths were removed, and PeA neurons were extracted via gentle suction with a fire-polished and Sigmacote (Sigma)-treated glass pipette. Neurons were plated on poly-L-lysine (Sigma)-coated coverslips glued on plastic dishes (Falcon, Franklin Lakes, NJ) (Wong et al., 1981) in the presence of CM (Ridgway et al., 1991) and were cultured at $20^{\circ} \mathrm{C}$.

cDNA library screening. PeA neurons were plated ( 8 per dish) $\sim 3-5$ soma diameters from each other. After $2 \mathrm{~d}$, neurites were transected at a distance of one soma diameter from the somata using a fire-polished pipette, and the somata were removed by gentle suction through the pipette. The remaining neurites were lysed in $200 \mu \mathrm{l}$ of $4 \mathrm{M}$ guanidine thiocyanate, and RNA was isolated as described by Chomczynski and Sacchi (1987). RNA was reverse transcribed into cDNA and amplified using the SMART PCR cDNA synthesis and amplification kit (Clontech, Mountain View, CA) following the manufacturer's instructions. Approximately $10 \mathrm{ng}$ of amplified cDNA was radiolabeled with $\left[{ }^{32} \mathrm{P}\right] \alpha$ dATP and used to screen $\sim 200,000$ clones of an amplified $\lambda$ ZAPII cDNA library of the CNS of L. stagnalis. Positive clones were isolated, replated at low density, and rehybridized for plaque purification. Circular plasmids were obtained by in vivo excision and sequenced in both orientations from universal primer sites present in the vector arms.

In situ hybridization. Cultured neurons were fixed in $1 \%$ paraformaldehyde $/ 1 \%$ acetic acid and permeabilized with $0.5 \% \mathrm{NP}-40$. Brains were fixed in $1 \%$ paraformaldehyde $/ 1 \%$ acetic acid and embedded in paraffin, and $7 \mu \mathrm{m}$ sections were adhered to $0.5 \%$ gelatin $/ 0.5 \%$ chromalumcoated slides. Digoxigenin-labeled run-off sense and antisense RNA were synthesized from linearized pBluescript plasmids using T3 or T7 RNA polymerase and a dioxigenin-UTP labeling mixture (both from Roche Diagnostics, Mannheim, Germany). In situ hybridizations were performed as described previously (Smit et al., 1996).

Quantitative PCR. Neurons were cultured (10-15 per dish) either in a configuration that produced multiple contacts between neurites or at such a distance that they grew out without ever contacting each other (8-10 dishes per condition). After $2 \mathrm{~d}$, RNA was isolated from the transected neurites and from the corresponding somata separately. After removal of DNA by DNaseI treatment, the RNA was random primed with $300 \mathrm{pmol}$ of random hexanucleotides and reverse transcribed into cDNA. qPCR was performed in triplicate on each cDNA sample using an ABI PRISM 7700 Sequence Detection System (Applied Biosystems, Foster City, CA) with SYBR Green as the reporter dye. All reactions were performed according to the instructions of the manufacturer. The following primers were used: $\beta$-thymosin (forward, $5^{\prime}$-CTGTGAGCCATCAAGCTGTTG-3'; reverse, $5^{\prime}$-GGTGTACATGGCATCCGATTT$3^{\prime}$ ) and mitochondrial $16 \mathrm{~S}$ rRNA (forward, $5^{\prime}$-ACCTTGACTGTGCTAAGGTAGCATAA-3'; reverse, 5' -CAGTTCTTCCCTATTAATCCGTTCAT- $3^{\prime}$ ). Overall cDNA expression levels per sample were normalized to the expression of $16 \mathrm{~S}$ rRNA.

dsRNA inhibition. A 400 bp cDNA fragment encoding Lymnaea $\beta$-thymosin was PCR-amplified using gene-specific primers extended on their 5' ends with T3 and T7 RNA promoter sequences, respectively. The PCR product was agarose gel purified and used to synthesize sense and antisense cRNA in two independent reactions using T3 and T7 RNA polymerase ( $2 \mathrm{~h}$ at $37^{\circ} \mathrm{C}$; Invitrogen). Reactions were briefly treated with RNase-free DNase $\left(10 \mathrm{~min}\right.$ at $37^{\circ} \mathrm{C}$; Roche Diagnostics), phenol extracted, and ethanol precipitated. Equimolar amounts of sense and antisense cRNA were hybridized for $16 \mathrm{~h}$ at $50^{\circ} \mathrm{C}$ in a solution containing 20 mM HEPES, $200 \mathrm{~mm} \mathrm{KCl,} 1 \mathrm{~mm}$ EDTA, and $\sim 100 \mathrm{ng} / \mathrm{ml}$ of each of the cRNAs (Korneev et al., 1999), after which $>95 \%$ of the cRNA had participated in the formation of dsRNA. As a negative control, a 450 bp
dsRNA was prepared, directed against the non-neuronal (glial) acetylcholine-binding protein (AChBP) transcript (Smit et al., 2001). PeA neurons were first cultured in the absence of dsRNA for $24 \mathrm{~h}$ at room temperature (RT) and then incubated for the next $24 \mathrm{~h}$ at $4^{\circ} \mathrm{C}$ in the presence of dsRNA ( $\sim 300 \mathrm{ng} / \mathrm{ml} \mathrm{CM})$. This temperature reduced the extent of neurite outgrowth during this initial dsRNA incubation time. After incubation at $4^{\circ} \mathrm{C}$ (at $t=0 \mathrm{~h}$ ), cells were again placed at RT to allow neurite outgrowth to resume, and the subsequent outgrowth was quantified over the next $3 \mathrm{~d}$ (at $t=24 \mathrm{~h}, t=48 \mathrm{~h}$, and $t=72 \mathrm{~h}$ ). Neurite length was measured for each primary neurite, from the cell body to the tip of the longest branch. For isolated neurite experiments, primary neurites were dissected after $\sim 24 \mathrm{~h}$ of growth, and neurites were incubated in dsRNA for $24 \mathrm{~h}$ at $4^{\circ} \mathrm{C}$. After incubation at $4^{\circ} \mathrm{C}($ at $t=0 \mathrm{~h})$, neurites were placed at RT again to allow neurite outgrowth to resume, and total neurite length (i.e., the primary neurite including all branches) was measured at $t=0 \mathrm{~h}, t=2 \mathrm{~h}, t=3 \mathrm{~h}$, and $t=24 \mathrm{~h}$. Two-way repeatedmeasures ANOVA and Dunn's-Bonferroni's corrected post hoc test were used to determine significance.

\section{Results \\ Identification and localization of $\beta$-thymosin mRNA in neurites of pedal A cells}

To identify transcripts that are present in neurites, we screened a Lymnaea brain-specific cDNA library using a cDNA probe derived from the neuritic compartment of cultured PeA neurons. One of the most abundant clones that we identified encoded the actin-binding protein $\beta$-thymosin (Fig. $1 A$ ). Only $\beta$-tubulin mRNA was more abundant. A list of all identified transcripts is available as supplemental material (Table 1, at www.jneurosci. org). Our findings confirm a recent study showing that tubulin and $\beta$-thymosin are also the most abundant transcripts in neurites of cultured Aplysia sensory neurons (Moccia et al., 2003). We used quantitative PCR (qPCR) to confirm the presence of $\beta$-thymosin mRNA in PeA neurites. PeA neurons were cultured in two different configurations. In the noncontact configuration, 10-15 neurons were cultured such that their neurites did not contact one another $(n=7)$. In the contact configuration, the same number of neurons were cultured such that, after $2 \mathrm{~d}$, $>50 \%$ of all neurites had made multiple contacts with one another $(n=8)$. These neuritic contacts form a physiologically relevant stimulus because they are known to develop into electrical synapses reflecting the electrical coupling of PeA cells in vivo (Syed and Winlow, 1989). Moreover, synapse formation in cultured Lymnaea neurons is known to suppress outgrowth (Feng et al., 2000). We found that, relative to $16 \mathrm{~S}$ rRNA, $\beta$-thymosin mRNA is approximately five times more abundant in neurites than in somata (Fig. $1 B$ ). This confirms that $\beta$-thymosin mRNA is indeed actively transported into neurites. However, we measured no differences in $\beta$-thymosin transcript levels between the two different culture configurations (i.e., contact vs noncontact), showing that neither somatic gene expression nor neuritic translocation of $\beta$-thymosin mRNA are affected by conditions that suppress neurite outgrowth.

Subsequently, we used in situ hybridization to study the expression of $\beta$-thymosin. In adult intact brains, $\beta$-thymosin expression was detected in all neurons (Fig. 1C), but no hybridization was detected in the neuropil and in nerves radiating from the brain. These findings confirm that the appearance of $\beta$-thymosin transcript in neurites is most likely attributable to a selective mRNA export mechanism that is active in outgrowing PeA neurons but not in adult, fully differentiated PeA neurons. In cultured PeA neurons, $\beta$-thymosin transcript was detected in neuronal cell bodies as well as in neurites (Fig. 1D). Interestingly, 
$\beta$-thymosin mRNA showed a highly differential distribution in neurites. We often observed both positively stained and unstained neurites originating from the same neuron (Fig. 1D) and accumulation of transcript at specific subneuritic sites (Fig. $1 E-H)$. These findings suggest that locally induced translation of $\beta$-thymosin could provide a regulatory mechanism in neurite outgrowth by affecting actin polymerization and subsequent growth cone advance in an immediate and branch-specific manner. Therefore, as a next step, we decided to block local $\beta$-thymosin translation and study the effects on neurite outgrowth.

\section{DsRNA inhibition of $\boldsymbol{\beta}$-thymosin enhances neurite extension of intact PeA cells}

We used dsRNA inhibition to knockdown $\beta$-thymosin mRNA levels in PeA cells. We first studied the effects of $\beta$-thymosin knockdown in intact PeA neurons. Before dsRNA incubation (at $t=-24 \mathrm{~h}$ ) and directly after dsRNA treatment (at $t=0 \mathrm{~h}$ ), we did not observe any difference in neurite outgrowth between $\beta$-thymosin dsRNA-treated cells and control dsRNAtreated cells or untreated control cells. However, over the subsequent $3 \mathrm{~d}$, neurites of cells incubated with $\beta$-thymosin dsRNA grew $\sim 3$ times longer than neurites of control cells (Fig. 2). At $t=24 \mathrm{~h}$ (i.e., $1 \mathrm{~d}$ after dsRNA treatment), cells incubated with $\beta$-thymosin dsRNA $(n=19)$ had a mean primary neurite length of $408 \pm 61 \mu \mathrm{m}$ (mean \pm SEM), which was significantly more than control dsRNAtreated cells $(156 \pm 28 \mu \mathrm{m} ; n=24 ; p<$ 0.01 ) and also more (although not significant) than untreated cells $(227 \pm 77 \mu \mathrm{m}$; $n=7)$. At $t=48 \mathrm{~h}$, mean primary neurite length of $\beta$-thymosin dsRNA-treated cells $(n=19)$ was $778 \pm 80$ $\mu \mathrm{m}$, which was significantly more than both control dsRNAtreated $(n=24)$ and untreated $(n=7)$ cells $(246 \pm 39$ and $288 \pm$ $103 \mu \mathrm{m}$, respectively; $p<0.01)$. Finally, at $t=72 \mathrm{~h}$, mean primary neurite length of $\beta$-thymosin dsRNA-treated cells was $861 \pm 102 \mu \mathrm{m}$, which was again significantly more than both control dsRNA-treated cells and untreated cells $(268 \pm 43$ and $337 \pm 105 \mu \mathrm{m}$, respectively; $n=7$ for all three conditions; $p<$ 0.01). The efficacy of dsRNA-mediated knockdown was confirmed with in situ hybridization (Fig. 2C). Importantly, the observed increase in primary neurite length was attributable to an increase in neurite outgrowth only and not to reduced branching. At $t=24 \mathrm{~h}, 50 \%$ of the $\beta$-thymosin dsRNA-treated neurites exhibited branching ( $n=22$ of 44$)$, and $32 \%$ of the control dsRNA-treated cells exhibited branching $(n=12$ of $38 ; p>0.05$; $\chi^{2}$ test). Also, the distance measured to the first branch for those neurites that did branch did not differ between $\beta$-thymosin dsRNA-treated cells $(145 \pm 19 \mu \mathrm{m} ; n=22)$ and control dsRNAtreated cells $(116 \pm 23 \mu \mathrm{m} ; n=12 ; p>0.05 ; t$ test $)$. Thus, $\beta$-thymosin knockdown significantly increased neurite length in
PeA neurons in primary culture, suggesting that $\beta$-thymosin normally serves to inhibit outgrowth in these cells.

\section{dsRNA inhibition of $\boldsymbol{\beta}$-thymosin enhances extension of isolated PeA neurites}

Subsequently, we asked whether knockdown of neuritic $\beta$-thymosin mRNA would have a similar effect on outgrowth of isolated neurites that lack mRNA or protein import from the cell body. To this end, we made use of the fact that isolated neurites of Lymnaea neurons (i.e., neurites that have been transected from their cell body) remain viable in culture for several days (Van Minnen et al., 1997). PeA neurons were cultured in the absence of dsRNA for $24 \mathrm{~h}$. Then, neurites were transected and incubated in dsRNA at $4^{\circ} \mathrm{C}$ for $24 \mathrm{~h}$, and their outgrowth was monitored for the next $24 \mathrm{~h}$ at $20^{\circ} \mathrm{C}$. Neurites treated with $\beta$-thymosin dsRNA showed enhanced neurite outgrowth; total length of these neurites (including branches) at $t=0,2,3$, and $24 \mathrm{~h}$ was $804 \pm 151$, $997 \pm 185,1142 \pm 207$, and $1657 \pm 306 \mu \mathrm{m}$, respectively (mean \pm SEM; $n=22$ ). Thus, neurites continued to grow for at least $24 \mathrm{~h}$ after $\beta$-thymosin dsRNA treatment, and total neurite 


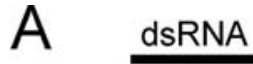

$-24 h$
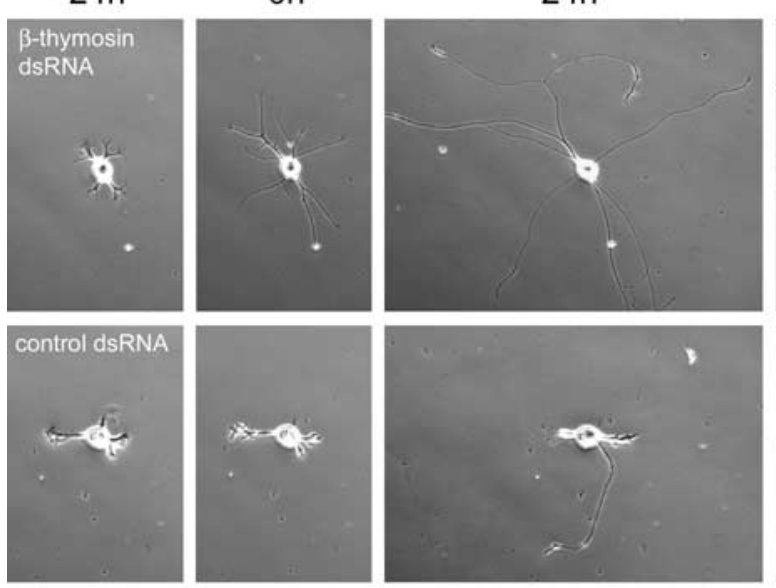

\section{B}
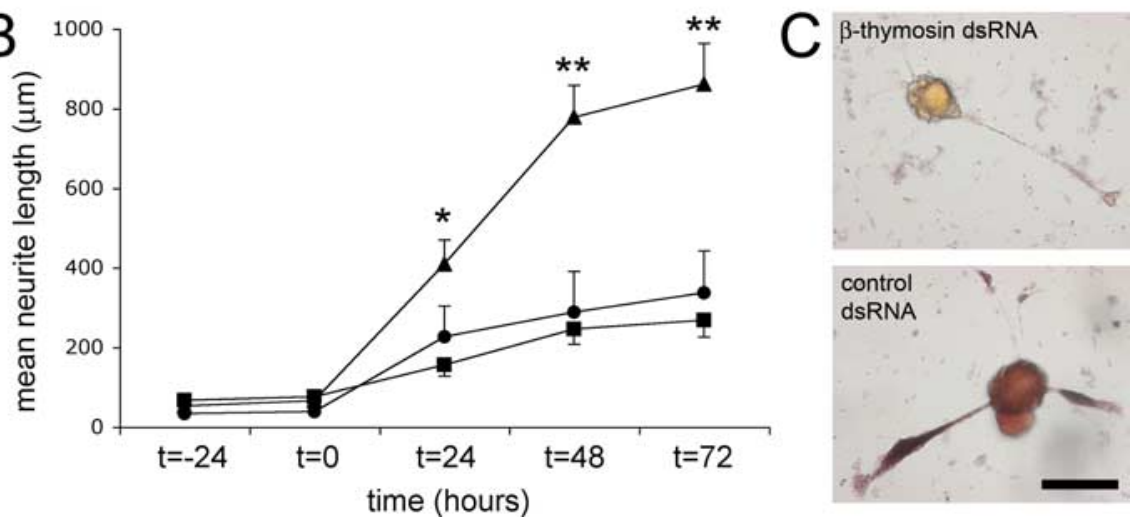

Figure 2. dsRNA inhibition of $\beta$-thymosin mRNA in intact cultured PeA neurons enhances neurite outgrowth. $\boldsymbol{A}$, Typical examples of neurite outgrowth under different conditions are depicted. The addition of $\beta$-thymosin dsRNA to PeA neurons in culture (top) resulted in an enhancement of neurite outgrowth compared with PeA neurons incubated with AChBP dsRNA (bottom). Photographs were taken at the indicated time points, and dsRNA was present as indicated (see Results for details). Scale bar, $100 \mu \mathrm{m}$. B, Quantification of the mean length of primary neurites showed a significant enhancement of neurite outgrowth in $\beta$-thymosin dsRNA-treated neurons (triangles; $n=19$ ) compared with AChBP dsRNA-treated neurons (squares; $n=24$ ) and untreated control neurons (circles; $n=7$ ) (mean \pm SEM; ${ }^{*} p<0.01$ for $\beta$-thymosin dsRNA-treated cells compared with AChBP dsRNA-treated cells, ${ }^{* *} p<0.01$ for $\beta$-thymosin dsRNA-treated cells compared with both controls; see Results for details). $\boldsymbol{C}$, Confirmation of $\beta$-thymosin mRNA downregulation after dsRNA treatment. Cells treated with $\beta$-thymosin dsRNA showed no in situ hybridization signal with a $\beta$-thymosin antisense probe (top; $n=15$ ), whereas control dsRNA-treated cells showed clear hybridization in both the soma and the neurites (bottom; $n=8$ ). Scale bar, $50 \mathrm{~mm}$.

length increased by $106 \%$ (Fig. 3). In contrast, neurites treated with the control dsRNA only showed a $59 \%$ increase in total neurite length. The total length of control neurites at $t=0,2,3$, and $24 \mathrm{~h}$ was $590 \pm 77,718 \pm 83,763 \pm 90$, and $936 \pm 140 \mu \mathrm{m}$, respectively $(n=22)$. Statistical analysis showed significant differences in total neurite length between $\beta$-thymosin dsRNAtreated neurites and control neurites at the last two time points (i.e., $t=3$ and $24 \mathrm{~h} ; p<0.01$ ).

\section{Discussion}

Local synthesis of cytoskeleton-associated proteins could provide an important regulatory mechanism in neurite outgrowth and growth cone motility (Campbell and Holt, 2001); however, direct evidence for local translation of specific cytoskeleton-regulatory proteins and a subsequent role in neurite outgrowth is still lacking. Here, we identified the actin-binding protein $\beta$-thymosin as a locally synthesized protein in neurites of outgrowing neurons in culture. Quantitative PCR measurements confirmed the presence of $\beta$-thymosin mRNA in cultured neurites, and in situ hybridization revealed that $\beta$-thymosin transcript tends to accumulate at particular subneuritic sites. These findings suggest that, after translation, $\beta$-thymosin is specifically required for particular aspects of neurite outgrowth, such as growth cone turning. This observation is in line with other studies showing that growth cone turning and pathfinding require local protein translation (Campbell and Holt, 2001; Brittis et al., 2002; Ming et al., 2002). Our observations of $\beta$-thymosin mRNA in neurites are restricted to regenerating PeA neurons in culture. However, because $\beta$-thymosin is an abundant protein in axons of developing neurons in other species (Border et al., 1993; Roth et al., 1999a), we assume that local translation of $\beta$-thymosin is not restricted to regenerating neurons and may be a widespread neuronal developmental phenomenon.

To study the functional contribution of local $\beta$-thymosin synthesis to neurite outgrowth, we decided to study the effects of $\beta$-thymosin mRNA knockdown on outgrowth. In intact PeA neurons, knockdown of $\beta$-thymosin mRNA clearly resulted in an increase in neurite outgrowth compared with untreated control cells or cells incubated with a negative control dsRNA. This threefold increase resulted from the measurement of primary neurites only. Thus, reducing $\beta$-thymosin levels increased neurite extension of primary neurites. Importantly, the increase in primary neurite length was not attributable to reduced branching, but rather to an increase in neurite outgrowth. These findings suggest that $\beta$-thymosin normally serves to inhibit outgrowth in these cells. Similar results were obtained in isolated neurites, i.e., $\beta$-thymosin dsRNA-treated neurites grew significantly longer than control neurites. Because the dsRNAs were added after transection of the neurites, the observed increase in neurite extension must be caused by a reduction of the local, neuritic $\beta$-thymosin mRNA pool, demonstrating that local translation of $\beta$-thymosin is involved in the control of neurite outgrowth. The effects were not as robust as in intact cells, which may be for a number of reasons. First, isolated neurites only have a limited capacity to continue growing, which is primarily caused by the limited amount of membrane available for growth. Second, it is possible that dsRNA inhibition is less efficient in isolated neurites because it requires soma-derived molecular machinery to be fully effective. Finally, in our experimental setup, we only considered basal levels of local $\beta$-thymosin translation. One might expect, however, that local translation is stimulus dependent, and that some kind of growth inhibiting stimulus would be required to expose the full extent of the effect of $\beta$-thymosin knockdown in isolated neurites. Nevertheless, the $\beta$-thymosin dsRNA-induced increase 

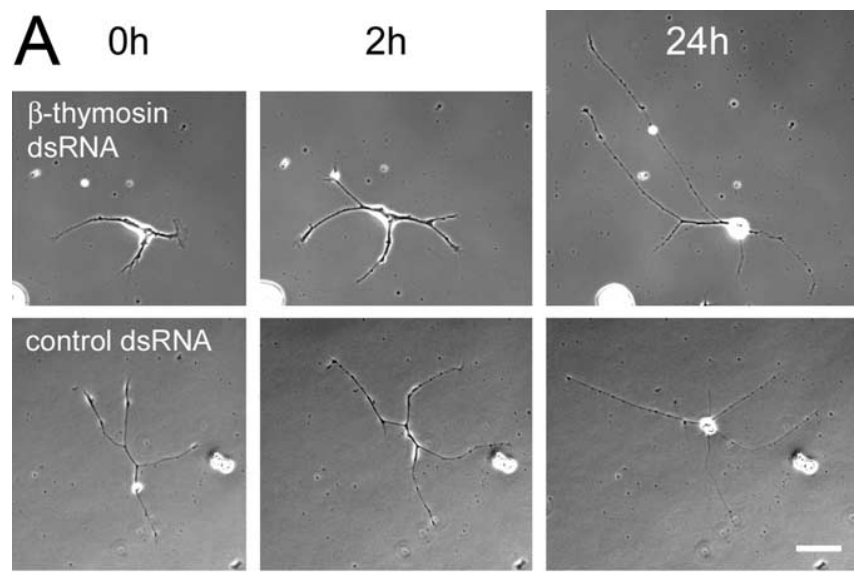

\section{B}

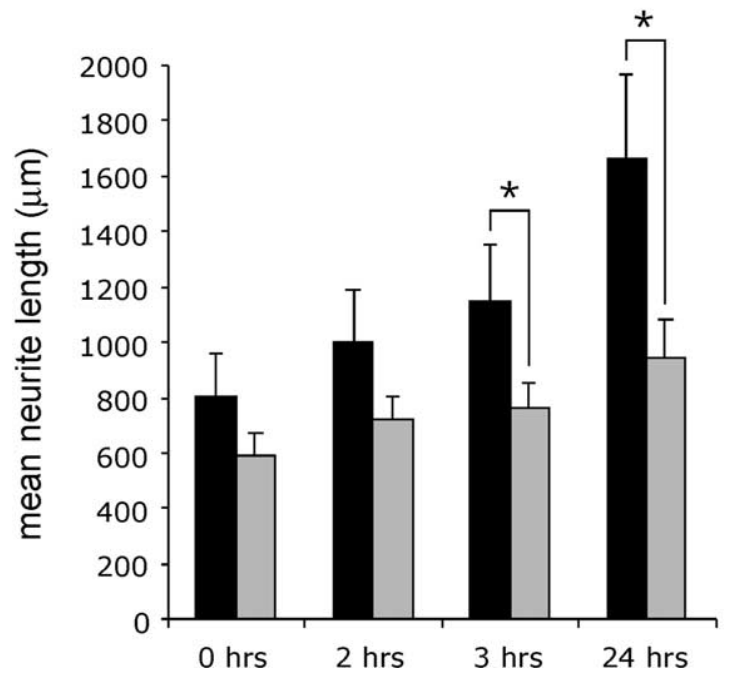

Figure 3. dsRNA inhibition of $\beta$-thymosin mRNA enhances outgrowth of transected PeA neurites. $\boldsymbol{A}$, Typical examples of neurite outgrowth of isolated neurites after incubation with $\beta$-thymosin dsRNA (top) or AChBP dsRNA (bottom). Photographs were taken immediately after dsRNA treatment $(t=0 \mathrm{~h}$ ), as well as 2 and $24 \mathrm{~h}$ later. Note that, in the top panels, the isolated soma is still visible in the bottom left corner of each photograph. Scale bar, $50 \mu \mathrm{m}$. B, Quantification of the total neurite length shows significantly enhanced outgrowth of $\beta$-thymosin dsRNA-treated neurites (black bars; $n=22$ ) compared with AChBP dsRNA-treated neurites (gray bars; $n=22$ ) (mean \pm SEM; * $p<0.01$; see Results for details).

in the outgrowth of isolated neurites was significant and unequivocally confirmed our findings obtained in intact cells. Together with the observed localization of $\beta$-thymosin transcript at turning points and in growth cones, our data support the hypothesis that local translation of $\beta$-thymosin plays a role in regulating neurite outgrowth.

Based on our findings, we propose that local synthesis of $\beta$-thymosin is required for normal patterns of neurite outgrowth. Our data are consistent with the idea that $\beta$-thymosin is locally synthesized in response to growth inhibitory constraints in the environment. Because $\beta$-thymosin is known to regulate the availability of G-actin for actin polymerization (Huff et al., 2001), a local increase in $\beta$-thymosin levels inside the growth cone will inhibit actin polymerization and cause a reduction in growth cone advance (see Fig. S1, available at www.jneurosci.org as supplemental material). Conversely, knocking down $\beta$-thymosin levels results in an inability of the growth cone to respond to growth-inhibiting signals in the environment and consequently enhances neurite outgrowth. There are indications that other actin-regulatory proteins, as well as actin itself, are also locally synthesized (Willis et al., 2005; Wu et al., 2005). Thus, the actin cytoskeleton and its associated regulatory proteins appear to be controlled by local translation, and future studies will have to elucidate how extracellular signals activate this mechanism in extending neurites and growth cones.

\section{References}

Border BG, Lin SC, Griffin WS, Pardue S, Morrison-Bogorad M (1993) Alterations in actin-binding $\beta$-thymosin expression accompany neuronal differentiation and migration in rat cerebellum. J Neurochem 61:2104-2114.

Brittis PA, Lu Q, Flanagan JG (2002) Axonal protein synthesis provides a mechanism for localized regulation at an intermediate target. Cell 110:223-235.

Campbell DS, Holt CE (2001) Chemotropic responses of retinal growth cones mediated by rapid local protein synthesis and degradation. Neuron 32:1013-1026.

Carpintero P, Anadon R, Diaz-Regueira S, Gomez-Marquez J (1999) Expression of thymosin $\beta 4$ messenger RNA in normal and kainate-treated rat forebrain. Neuroscience 90:1433-1444.

Chomczynski P, Sacchi N (1987) Single-step method of RNA isolation by acid guanidinium thiocyanate- phenol-chloroform extraction. Anal Biochem 162:156-159.

Dent EW, Gertler FB (2003) Cytoskeletal dynamics and transport in growth cone motility and axon guidance. Neuron 40:209-227.

Devineni N, Minamide LS, Niu M, Safer D, Verma R, Bamburg JR, Nachmias VT (1999) A quantitative analysis of G-actin binding proteins and the G-actin pool in developing chick brain. Brain Res 823:129-140.

Dos Remedios CG, Chhabra D, Kekic M, Dedova IV, Tsubakihara M, Berry DA, Nosworthy NJ (2003) Actin binding proteins: regulation of cytoskeletal microfilaments. Physiol Rev 83:433-473.

Feng ZP, Hasan SU, Lukowiak K, Syed NI (2000) Target cell contact suppresses neurite outgrowth from soma-soma paired Lymnaea neurons. J Neurobiol 42:357-369.

Glanzer JG, Eberwine JH (2003) Mechanisms of translational control in dendrites. Neurobiol Aging 24:1105-1111.

Huff T, Muller CS, Otto AM, Netzker R, Hannappel E (2001) $\beta$-Thymosins, small acidic peptides with multiple functions. Int J Biochem Cell Biol 33:205-220.

Korneev SA, ParkJH, O’Shea M (1999) Neuronal expression of neural nitric oxide synthase (nNOS) protein is suppressed by an antisense RNA transcribed from an NOS pseudogene. J Neurosci 19:7711-7720.

Martin KC (2004) Local protein synthesis during axon guidance and synaptic plasticity. Curr Opin Neurobiol 14:305-310.

Ming GL, Wong ST, Henley J, Yuan XB, Song HJ, Spitzer NC, Poo MM (2002) Adaptation in the chemotactic guidance of nerve growth cones. Nature 417:411-418.

Moccia R, Chen D, Lyles V, Kapuya E, E Y, Kalachikov S, Spahn CM, Frank J, Kandel ER, Barad M, Martin KC (2003) An unbiased cDNA library prepared from isolated Aplysia sensory neuron processes is enriched for cytoskeletal and translational mRNAs. J Neurosci 23:9409-9417.

Piper M, Holt C (2004) RNA translation in axons. Annu Rev Cell Dev Biol 20:505-523.

Ridgway RL, Syed NI, Lukowiak K, Bulloch AG (1991) Nerve growth factor (NGF) induces sprouting of specific neurons of the snail, Lymnaea stagnalis. J Neurobiol 22:377-390.

Roth LW, Bormann P, Bonnet A, Reinhard E (1999a) $\beta$-Thymosin is required for axonal tract formation in developing zebrafish brain. Development 126:1365-1374.

Roth LW, Bormann P, Wiederkehr C, Reinhard E (1999b) $\beta$-Thymosin, a modulator of the actin cytoskeleton is increased in regenerating retinal ganglion cells. Eur J Neurosci 11:3488-3498.

Smit AB, Spijker S, Van Minnen J, Burke JF, De Winter F, Van Elk R, Geraerts WP (1996) Expression and characterization of molluscan insulinrelated peptide VII from the mollusc Lymnaea stagnalis. Neuroscience 70:589-596.

Smit AB, Syed NI, Schaap D, van Minnen J, Klumperman J, Kits KS, Lodder H, van der Schors RC, van Elk R, Sorgedrager B, Brejc K, Sixma TK, 
Geraerts WP (2001) A glia-derived acetylcholine-binding protein that modulates synaptic transmission. Nature 411:261-268.

Syed NI, Winlow W (1989) Morphology and electrophysiology of neurons innervating the ciliated locomotor epithelium in Lymnaea stagnalis (L.). Comp Biochem Physiol 93A:633-644.

Syed NI, Bulloch AG, Lukowiak K (1990) In vitro reconstruction of the respiratory central pattern generator of the mollusk Lymnaea. Science 250:282-285.

Van der Steen WJ (1969) A method for breeding and studying freshwater snails under continuous water change, with some remarks on growth and reproduction in Lymnaea stagnalis. Neth J Zool 19:131-139.

Van Minnen J, Bergman JJ, Van Kesteren ER, Smit AB, Geraerts WP, Lukow- iak K, Hasan SU, Syed NI (1997) De novo protein synthesis in isolated axons of identified neurons. Neuroscience 80:1-7.

Willis D, Li KW, Zheng JQ, Chang JH, Smit A, Kelly T, Merianda TT, Sylvester J, van Minnen J, Twiss JL (2005) Differential transport and local translation of cytoskeletal, injury-response, and neurodegeneration protein mRNAs in axons. J Neurosci 25:778-791.

Wong RG, Hadley RD, Kater SB, Hauser GC (1981) Neurite outgrowth in molluscan organ and cell cultures: the role of conditioning factor(s). J Neurosci 1:1008-1021.

Wu KY, Hengst U, Cox LJ, Macosko EZ, Jeromin A, Urquhart ER, Jaffrey SR (2005) Local translation of RhoA regulates growth cone collapse. Nature 436:1020-1024. 